\title{
Desain dan Implementasi Soft Switching Boost Konverter Dengan Simple Auxillary Resonant Switch (SARC)
}

\author{
Dimas Bagus Saputra, Heri Suryoatmojo, dan Arif Musthofa \\ Jurusan Teknik Elektro, Fakultas Teknologi Industri, Institut Teknologi Sepuluh Nopember (ITS) \\ J1. Arief Rahman Hakim, Surabaya 60111 \\ E-mail: dimas.bagus.saputra13@ee.its.ac.id; suryomgt@ee.its.ac.id; arif@ee.its.ac.id
}

\begin{abstract}
Abstrak - Boost konverter merupakan penaik tegangan DC ke tegangan DC yang mempunyai tegangan output yang lebih tinggi dibanding inputnya. Penggunaan boost konverter diera modern semakin meningkat dan dibuat dengan dimensi yang lebih kecil, berat yang lebih ringan dan efisiensi yang lebih tinggi dibanding dengan boost konverter generasi terdahulu. Tetapi rugi-rugi periodik saat on/off meningkat. Untuk meraih kriteria tersebut, teknik hard switching boost konverter berevolusi menjadi teknik soft switching dengan menambah rangkaian simple auxiliary resonant circuit (SARC). Karena penambahan rangkaian SARC tersebut konverter bekerja pada kondisi zero-voltage switching switch (ZVS) dan zero current switch (ZCS), sehingga saklar semikonduktor tidak bekerja secara hard switching lagi.

Pada penelitian ini akan di desain dan diimplementaskan soft switching boost konverter dengan SARC. Kelebihan dari soft switching boost konverter dengan SARC adalah mempunyai efisiensi yang lebih tinggi dibanding dengan boost konverter konventional. Dari hasil implementasi menunjukkan konverter yang diajukan telah meraih zero voltage switch (ZVS). Sehingga boost konverter zero voltage switch (ZVS) bisa diaplikasikan pada sistem power suplay yang membutuhkan efisiensi energi yang tinggi terutama pada daya yang tinggi.
\end{abstract}

Kata kunci: soft switching konverter, simple auxilary resonant switch, dc-dc konvensinal konverter.

\section{PENDAHULUAN}

Power suplay mode switching sekarang ini dibuat semakin kecil dan semakin ringan karena frekuensi pensaklarannya dinaikan, akibatnya rugi-rugi rugi-rugi periodik saat on/off juga meningkat. Untuk mengurangi rugi-rugi pensaklaran tersebut digunakan teknik soft switching. Saklar semikonduktor boost konverter konvensional bekerja pada kondisi hard switching sehingga masih terjadi rugi-rugi periodik saat on/off [1]. Untuk menaikkan efisiensi boost konverter konvensional maka teknik switching konverter tersebut harus dari hard switching menjadi soft switching. Upaya tersebut dapat dilakukan dengan memberi rangkaian tambahan simple auxiliary resonant switch (SARC) agar switching bekerja dikondisi zero voltage switch (ZVS) dan zero current switch (ZCS) sehingga saklar semikonduktor tidak bekerja secara hard switching lagi [1]. Didalam penelitian ini akan diimplementasikan boost konverter soft switching dengan SARC kemudian membandingkan efisiensinya dengan boost konverter konvensional, sehingga akan diketahui topologi konverter manakah yang memilki efisiensi lebih baik.

\section{URAIAN PENELITIAN}

A. Boost Konverter Soft Switching dengan Tambahan Rangkaian Simple Auxilarry Resonant Circuit (SARC).

Semakin berkembangnya tuntutan zaman maka konverter harus mempunyai efisiensi yang bagus, boost konverter bekerja secara hard switching sehingga terjadi rugi-rugi periodik saat saklar on/off, sehingga dilakukan teknik pensaklaran soft switching untuk mngurang rugi-rugi periodik tersebut, boost konverter soft switching dengan tambahan SARC mampu memperbaiki kekurangan boost konverter konvensional tersebut [1]. Boost konverter soft switching ini terdiri dari rangkaian boost konverter konvensional yang ditambahi lagi dengan rangkaian SARC, rangkaian SARC terdiri dari sebuah saklar auxillary $\left(\mathrm{S}_{2}\right)$, dioda switching $\left(\mathrm{D}_{2}, \mathrm{D}_{3}\right)$, sebuah resonant induktor $\left(\mathrm{L}_{\mathrm{r}}\right)$ dan sebuah resonant kapasitor $\left(\mathrm{C}_{\mathrm{r}}\right)$. Gambar rangkaian soft switching boost konverter dengan SARC ditunjukan gambar 1 sedangkan gambar bentuk gelombang soft switching boost konverter dengan SARC secara teori ditunjukan gambar 2.

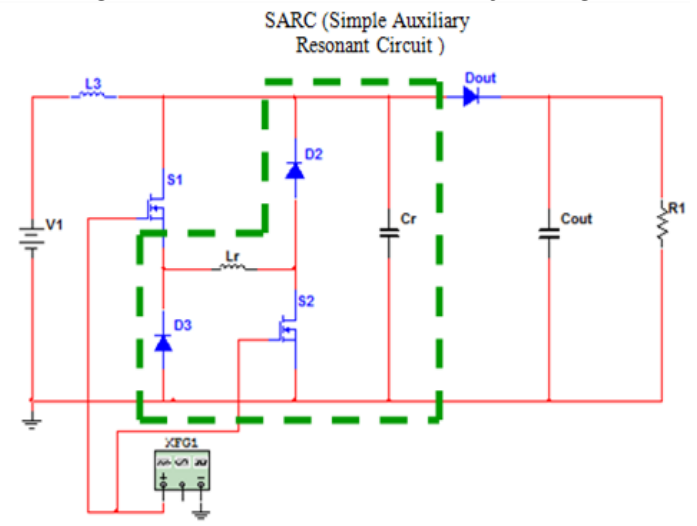

Gambar 1. Rangkaian soft switching boost konverter dengan SARC [1]

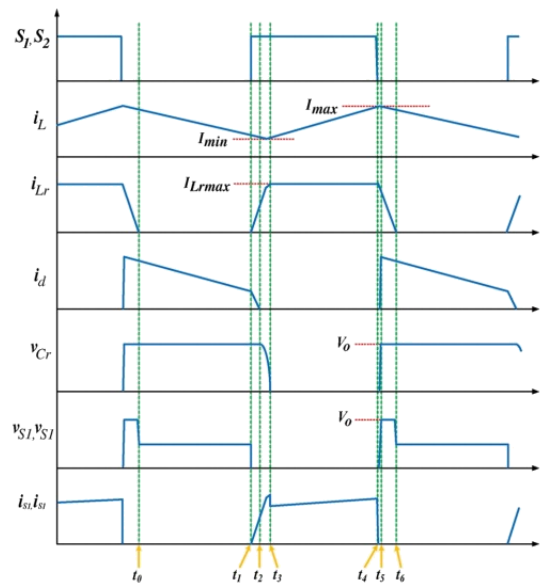

Gambar 2 Pengoperasian soft switching boost konverter dengan SARC [1]. 
Berdasarkan gambar 2 prinsip kerja soft switching boost konverter dengan SARC dibagi menjadi beberapa interval sebagai berikut [1]:

a. Interval $1\left(\mathrm{t}_{0}-\mathrm{t}_{1}\right)$

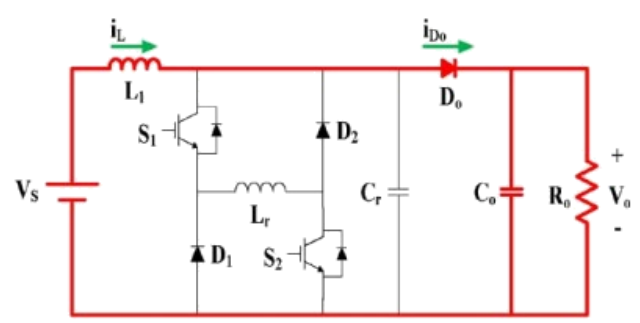

Gambar 3 Rangkaian ekivalen interval 1 [1].

Saat switches $\left(\mathrm{S}_{1}, \mathrm{~S}_{1}\right)$ off, arus induktor utama $\left(\mathrm{i}_{\mathrm{L}}\right)$ mengalir kebeban melalui $D_{o}$ dan $i_{L}$ menurun secara linier tidak sampai nol, arah aliran arus saat interval 1 ditunjukkan gambar 3.

$\mathrm{V}_{\mathrm{L}}(\mathrm{t})=\mathrm{V}_{\mathrm{s}}-\mathrm{V}_{\mathrm{o}}$

$\mathrm{i}_{\mathrm{L}}(\mathrm{t})=\mathrm{i}_{\mathrm{L}}(\mathrm{t} 0)-\frac{V o-V s}{L} \mathrm{t}$

$\mathrm{i}_{\mathrm{D} 0}(\mathrm{t})=\mathrm{i}_{\mathrm{L}}(\mathrm{t})$

$\mathrm{i}_{\mathrm{Lr}}(\mathrm{t})=0$

$\operatorname{Vcr}(\mathrm{t})=\mathrm{V}_{\mathrm{o}}$

b. Interval $2\left(\mathrm{t}_{1}-\mathrm{t}_{2}\right)$

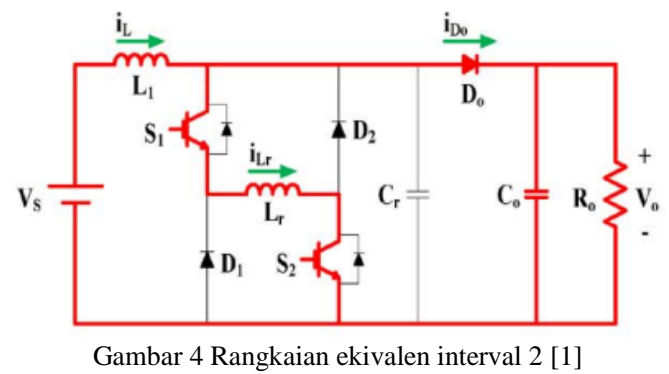

Saat $t_{1}$, switches $\left(\mathrm{S}_{1}, \mathrm{~S}_{2}\right)$ secara serentak dihidupkan dengan kondisi ZCS, hal ini terjadi karena resonant inductor $\mathrm{L}_{\mathrm{r}}$. Arus resonant induktor mulai naik secara linear. Mode ini selesai ketika arus induktor resonant sebanding dengan arus induktor utama. Arah aliran arus saat interval 2 ditunjukkan gambar 4.

$\mathrm{i}_{\mathrm{Lr}}\left(\mathrm{t}_{1}\right)=0 ; \mathrm{V}_{\mathrm{Lr}}(\mathrm{t})=\mathrm{V}_{\mathrm{o}}$

$\mathrm{i}_{\mathrm{Lr}}(\mathrm{t})=\frac{V o}{L r} t$

c. Interval $3\left(\mathrm{t}_{2}-\mathrm{t}_{3}\right)$

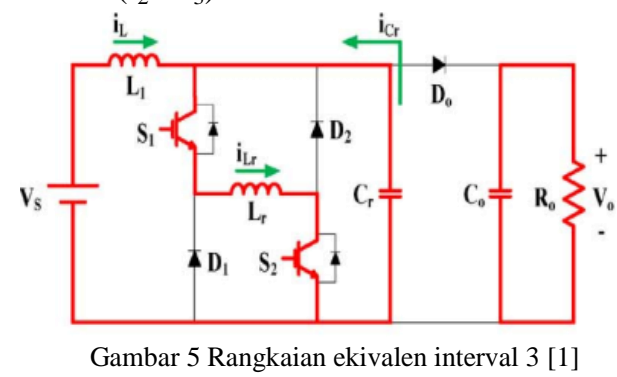

Mode 3 merupakan mode resonant. Saat dioda off, $\mathrm{L}$ dan $\mathrm{C}_{\mathrm{r}}$ mulai beresonansi. Tegangan kapasitor resonant turun akibat proses resonansi tersebut. Arah aliran arus saat interval 3 ditunjukkan gambar 5.

$\omega=\frac{1}{\sqrt{L \times C r}}$
$\mathrm{Z}_{\mathrm{r}}=\sqrt{\frac{L}{C r}}$

d. Interval $4\left(\mathrm{t}_{3}-\mathrm{t}_{4}\right)$

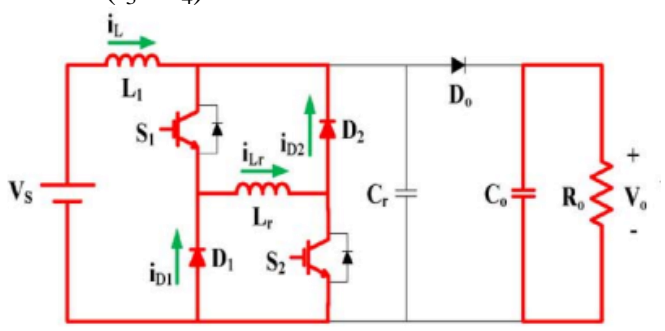

Gambar 6 Rangkaian ekivalen interval 4 [1]

Saat memasuki $\mathrm{t}_{3}$, resonant dioda $\left(\mathrm{D}_{3}, \mathrm{D}_{4}\right)$ on. $\mathrm{i}_{\mathrm{Lr}}$ mengalir melalui dua jalur freewheeling, yaitu $\mathrm{S}_{1}-\mathrm{L}_{\mathrm{r}}-\mathrm{D}_{2}$ dan $\mathrm{S}_{2}-\mathrm{D}_{1}-\mathrm{L}_{\mathrm{r}}$. Arus $\mathrm{i}_{\mathrm{L}}$ mulai meningkat secara linier dan jalur aliran arus $\mathrm{i}_{\mathrm{L}}$ adalah $\mathrm{L}-\mathrm{S}_{1}-\mathrm{L}_{\mathrm{r}}-\mathrm{S}_{2}$. Tegangan $\mathrm{V}_{\mathrm{Cr}}$ menjadi nol dan tegangan induktor utama $\left(\mathrm{V}_{\mathrm{L} 1}\right)$ sebanding dengan $\mathrm{V}_{\mathrm{s}}$, arah aliran arus saat interval 4 ditunjukkan gambar 6 .

$\mathrm{i}_{\mathrm{Lr}}(\mathrm{t})=\mathrm{i}_{\mathrm{L}}(\mathrm{t})+\mathrm{i}_{\mathrm{D} 1}(\mathrm{t})+\mathrm{i}_{\mathrm{D} 2}(\mathrm{t})$

$i_{\text {Lr }}(t 3)=i_{\text {Lr }}(t 4)=i_{\text {Lr maks }}$

e. Interval $5\left(t_{4}-t_{5}\right)$

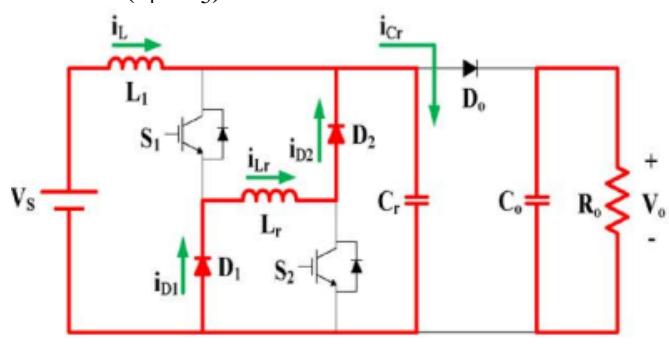

Gambar 7 Rangkaian ekivalen interval 5 [1]

Mode ini dimulai ketika $S_{1}$ dan $S_{2}$ dimatikan pada kondisi ZVS akibat dari $C_{r}$. $L_{r}$ dan $C_{r}$ mulai beresonansi. Arus $i_{L r}$ menurun karena proses resonansi dan $\mathrm{V}_{\mathrm{Cr}}$ naik dari nol naik hingga sebesar $\mathrm{V}_{\mathrm{o}}$ karena proses resonansi tersebut, arah aliran arus saat interval 5 ditunjukkan gambar 7 .

$\mathrm{i}_{\mathrm{Lr}}(\mathrm{t} 4)=\mathrm{i}_{\mathrm{Lr} \text { maks }}$

$\mathrm{i}_{\text {Lr }}(\mathrm{t})=\mathrm{i}_{\max }-\left(\mathrm{i}_{\max }+\mathrm{i}_{\text {Lrmaks }}\right) \cos _{\omega \mathrm{rt}}$

$\mathrm{V}_{\mathrm{cr}}\left(\mathrm{t}_{4}\right)=0$

$\mathrm{V}_{\mathrm{cr}}(\mathrm{t})=\mathrm{Z}_{\mathrm{r}}\left(\mathrm{i}_{\text {maks }}+\mathrm{i}_{\text {Lrmaks }}\right) \sin _{\omega \mathrm{rt}}$

$\mathrm{V}_{\text {cr }}\left(\mathrm{t}_{5}\right)=\mathrm{V}_{\mathrm{o}}$

f. Interval $6\left(\mathrm{t}_{5}-\mathrm{t}_{6}\right)$

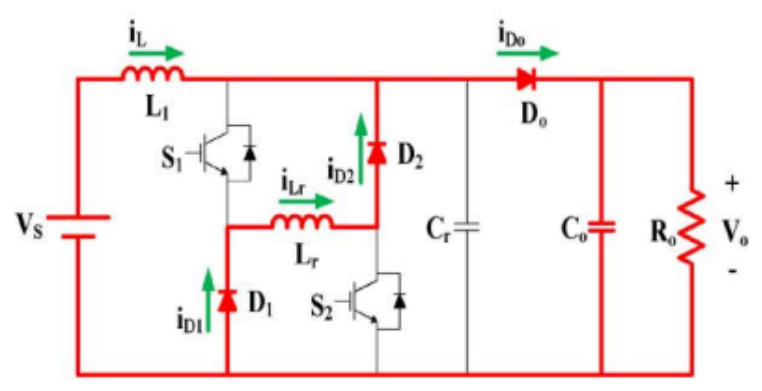

Gambar 8. Rangkaian ekivalen interval 6 [1]

Arus $i_{L}$ dan arus $i_{\text {Lr }}$ diakumulasi dan arah arus listriknya mengalir menuju output melalui $\mathrm{D}_{1}$. $\mathrm{i}_{\mathrm{Lr}}$ besarnya menurun menjadi nol selama mode ini, periode ini selesai ketika $i_{L r}$ 
telah berkurang menjadi sebesar nol, arah aliran arus saat interval 6 ditunjukkan gambar 8 .

$\mathrm{i}_{\mathrm{D} 0}(\mathrm{t})=\mathrm{i}_{\mathrm{L}}(\mathrm{t})+\mathrm{i}_{\mathrm{Lr}}(\mathrm{t})$

$\left.\mathrm{i}_{\mathrm{L}} \mathrm{t}\right)=\mathrm{i}_{\max }-\frac{V o-V s}{L r} t$

$\mathrm{i}_{\mathrm{Lr}}(\mathrm{t})=\mathrm{i}_{\mathrm{Lr}}\left(\mathrm{t}_{6}\right)-\frac{V o}{L r} t ; \mathrm{i}_{\mathrm{Lr}}\left(\mathrm{t}_{6}\right)=0$

\section{DESAIN, SIMULASI DAN IMPLEMENTASI}

Modul soft switching boost konverter dengan SARC pada penelitian ini terdiri dari dua blok utama, yaitu blok rangkaian daya dan blok kontrol. Gambar 9 memperlihatkan blok hardware. Blok kontrol terdiri dari pembangkit PWM dan kontroler close loop menggunakan IC SG3525 dan driver MOSFET menggunakan IC IR2110. Sedangkan blok rangkaian daya terdiri dari power supply dan soft switching boost konverter dengan tambahan rangkaian simple auxillary resonant circuit (SARC).

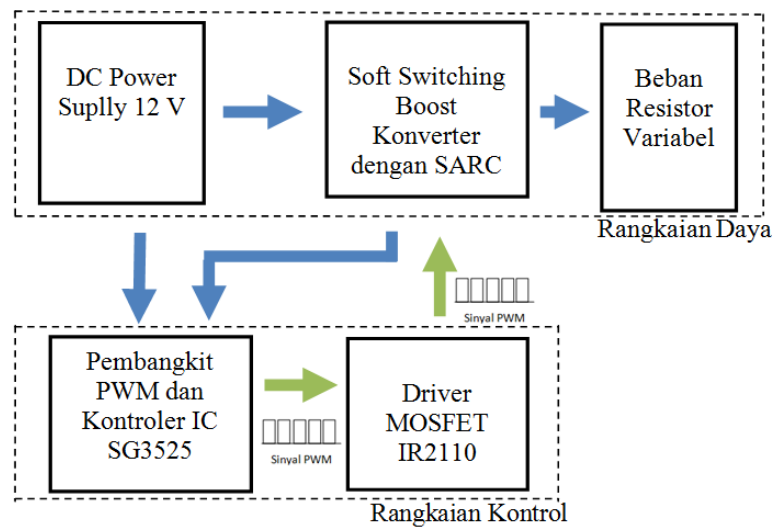

Keterangan:

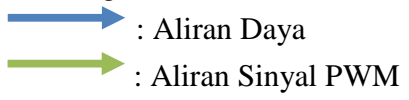

Gambar 9. Blok diagram hardware

\section{A. Perancangan Pembangkit Sinyal PWM}

Perancangan pembangkit frekuensi dan sinyal PWM dilakukan dengan menggunakan IC SG3525, IC jenis ini dipilih karena mempunyai fasilitas close loop. Rangkaian hardware ditunjukkan oleh gambar 10

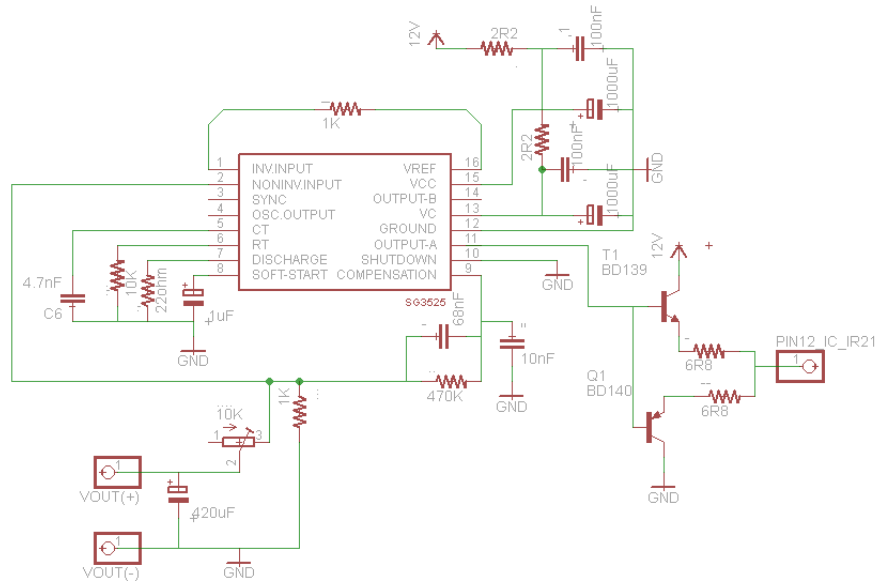

Gambar 10 Rangkaian pembangkit PWM SG3525

Frekuensi output dapat dihitung dengan menggunakan rumus berikut:

$$
\begin{aligned}
& \mathrm{f}_{\mathrm{s}}=\frac{1}{(\mathrm{CT}(0.7 * \mathrm{RT}+3 * \mathrm{R} \text { discharge }))} \\
& \text { dimana }: \mathrm{R}_{\mathrm{T}}=10 \mathrm{k} \Omega ; \mathrm{C}_{\mathrm{T}}=4.7 \mathrm{nF} ; \mathrm{R}_{\text {discharge }}=22 \Omega \\
& \text { Maka, } \mathrm{f}_{\mathrm{s}}=\frac{1}{(\mathrm{CT}(0.7 * 10000+3 * 22))} \\
& \mathrm{f}_{\mathrm{s}}=30.111 \mathrm{khz}
\end{aligned}
$$

\section{B. Perancangan Driver MOSFET}

Sinyal PWM yang dibangkitkan oleh IC SG3525 kemudian masuk kedriver MOSFET. Driver MOSFET yang digunakan adalah IR2110, mempunyai saluran keluaran sisi tinggi dan sisi rendah yang independen.

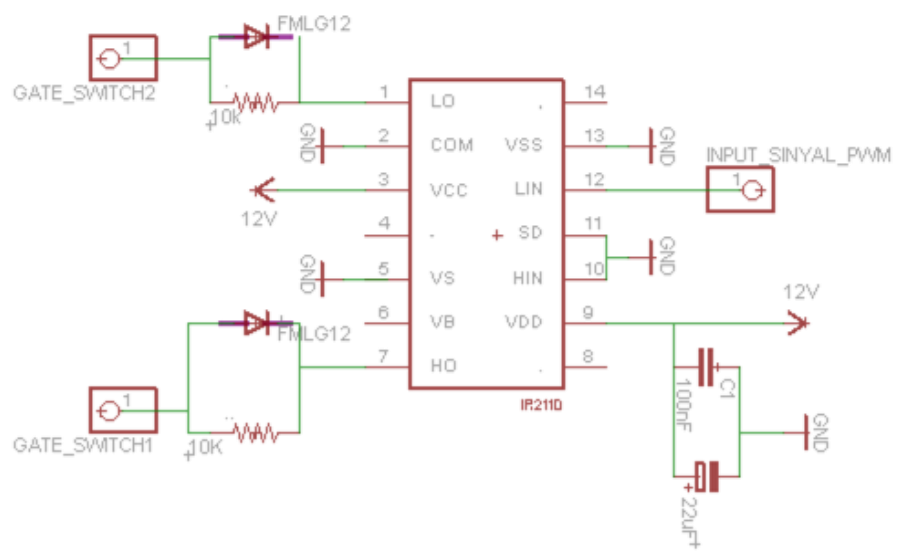

Gambar 11. Rangkaian driver MOSFET

\section{Perancangan Soft Switching Boost Konverter dengan SARC}

Soft switching boost konverter dengan SARC merupakan boost konverter konvensional yang ditambah dengan rangkaina simple auxiliary resonant circuit (SARC), sehingga memiliki dua buah saklar yaitu saklar utama $\left(\mathrm{S}_{1}\right)$ dan saklar auxillary $\left(\mathrm{S}_{2}\right)$. Parameter- parameter awal perencanaan ditunjukkan oleh tabel 1 .

$$
\text { Tabel } 1
$$

Parameter-parameter perancangan boost konverter soft switching dengan

\begin{tabular}{lc}
\multicolumn{2}{c}{ SARC } \\
\hline \hline $\mathrm{V}_{\text {in }}$ (tegangan input) $=$ & $10-12 \mathrm{~V}$ \\
$\mathrm{~V}_{\text {out }}$ (tegangan output) $=$ & $18 \mathrm{~V}$ \\
$\mathrm{f}_{\mathrm{s}}$ (frekuensi switching) $=$ & $30 \mathrm{kHz}$ \\
$\mathrm{i}_{\text {out }}$ (arus output) $=$ & $2.22 \mathrm{~A}$ \\
$\mathrm{P}_{\text {out }}$ (daya output $)=$ & 40 watt
\end{tabular}

Berikut proses tahapan perancangan komponen soft switching boost konverter dengan SARC :

a. Menghitung dutty cycle

$$
\begin{aligned}
& \mathrm{D}=1-\frac{V s}{V o} \\
& \mathrm{D}=1-\frac{12}{18} \\
& \mathrm{D}=0.666
\end{aligned}
$$

b. Menghitung nilai induktansi induktor

$$
\begin{aligned}
& \mathrm{i}_{\mathrm{L}}=\frac{\text { Iout }}{1-D} \\
& \mathrm{i}_{\mathrm{L}}=\frac{2.22}{2.22-0.666} \\
& \mathrm{i}_{\mathrm{L}}=1.43 \mathrm{~A}
\end{aligned}
$$


$\Delta \mathrm{i}=50 \% \times 1.43$

$\Delta \mathrm{i}=0.71$

$L=\frac{V s(V o-V s)}{f \Delta \mathrm{IVo}}$

$L=\frac{12(18-12)}{30000 \times 0.715 \times 18}$

$L=186.48 \mathrm{uH} \approx 200 \mathrm{uH}$

c. Menghitung jumlah lilitan induktor

Jika maxsimum ferrit fkux tidak diketahui maka nilai Bmax yang digunakan 0.3-0.35.

$N=\frac{L * i \max }{B \max * A C} \times 10^{4}$

$N=\frac{200 u H * 2.2 A}{0.3 * 1.42} \times 10^{4}$

$N=10.32 \mathrm{~N} \approx 10 \mathrm{~N}$

d. Menentukan luas penampang kawat induktor

$$
\begin{aligned}
& \mathrm{I}_{\mathrm{rms}}=\sqrt{i L^{2}+\left(\frac{\frac{\Delta i L}{2}}{\sqrt{3}}\right)^{2}} \\
& \mathrm{i}_{\mathrm{rms}}=\sqrt{1.43^{2}+\left(\frac{\frac{0.175}{2}}{\sqrt{3}}\right)^{2}}
\end{aligned}
$$

Irms $=1.43 A 8 \mathrm{~A}$

kawat penampang induktor sebesar $0.4 \mathrm{~mm}^{2}$

e. Menghitung nilai kapasitansi kapasitor

$\Delta \mathrm{Vc}=0.11 \% \times \mathrm{Vo}$

$\Delta \mathrm{Vc}=0.11 \% \times 18$

$\Delta \mathrm{Vc}=0.02$

$C=\frac{I o(V o-V i)}{V o f \Delta \mathrm{Vc}}$

$C=\frac{1.1(18-12)}{18.30000 .0 .02}$

$C=0.000611 \mathrm{~F} \approx 500 \mathrm{uF}$

f. Menentukan nilai kapasitor resonansi dan induktor resonansi

$\mathrm{Cr}=20 \mathrm{nF}$

$2 \pi f r=\frac{0.17775}{L r . C r}$

$2 \times 3.14 \times 30000=\frac{0.17775}{\operatorname{Lr} .20 \times 10^{-9}}$

$L r=47.175 \mathrm{uH}$

Gambar implementasi hardware dari perancangan soft switching boost konverter dengan SARC diatas ditunjukkan oleh gambar 12

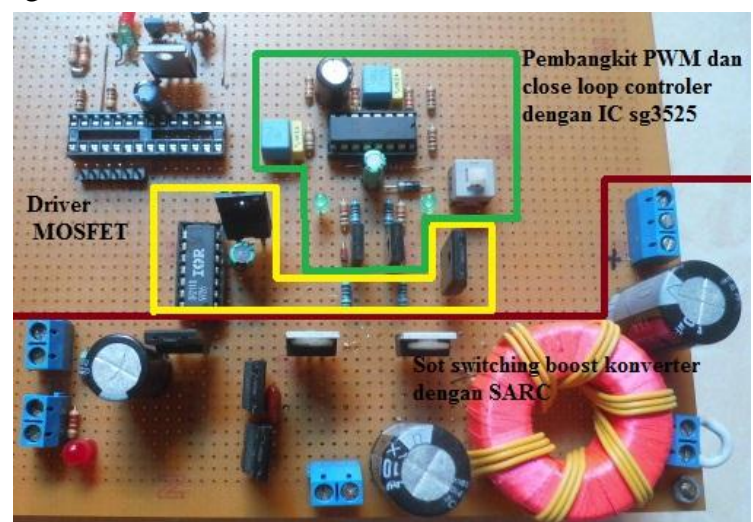

Gambar 12 Hardware soft switching boost konverter dengan SARC

\section{Perancangan Simulasi Boost Konverter dengan SARC}

Perancangan simulasi SARC boost konverter dibuat menggunakan program simulasi multisim yang ditunjukkan oleh gambar 13. Hasil simulasi menunjukkan soft switching boost konverter dengan SARC telah meraih zero voltage switch (ZVS) dan zero current switch (ZCS), seperti yang ditunjukkan oleh gambar 14.

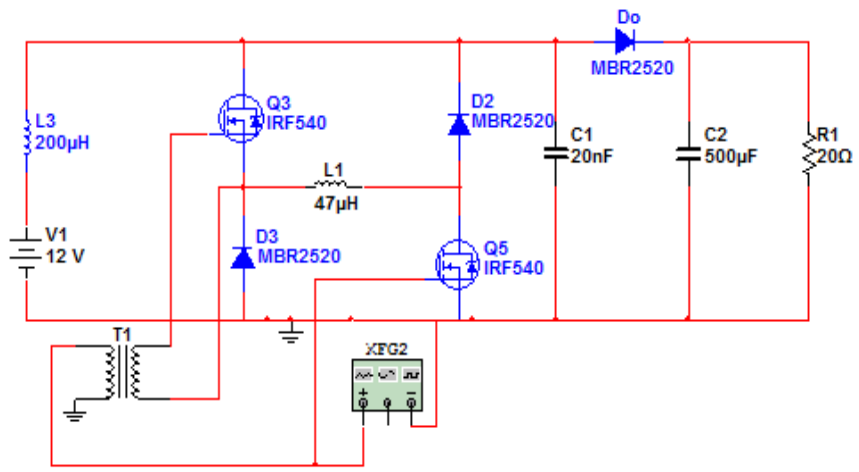

Gambar 13 Rangkaian simulasi konverter

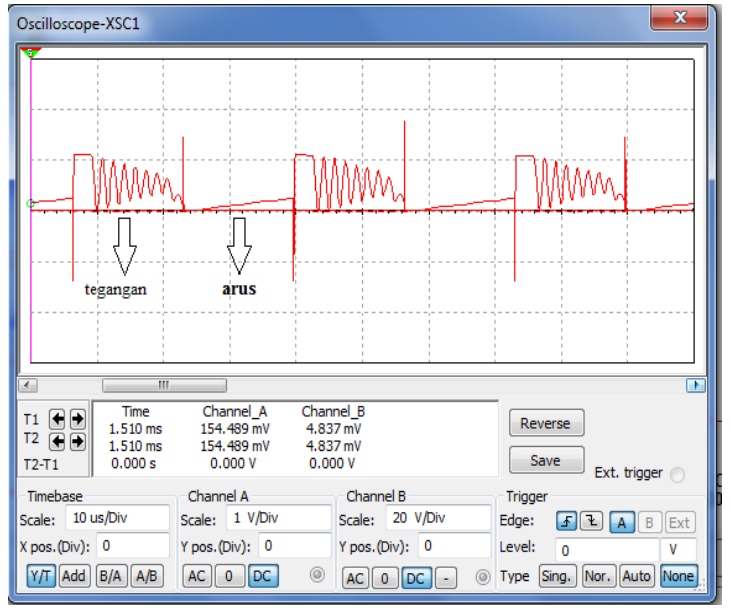

Gambar 14. Bentuk gelombang arus (channel B) dan gelombang tegangan(channel A) .

\section{IV.PENGUJIAN}

\section{A. Pengujian kontrol Close Loop IC SG3525}

Grafik perubahan dutty cycle saat tegangan input dan output tetap dan beban berubah dengan set point $18 \mathrm{~V}$ ditunjukkan oleh gambar 15 .

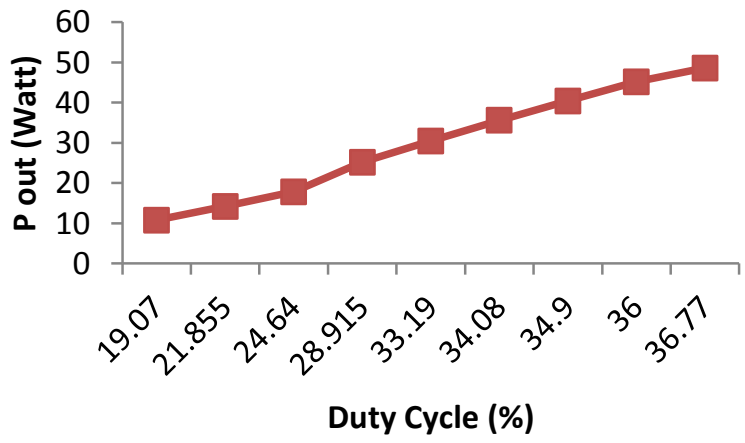

Gambar 15 Hubungan dutty cycle dan Pout 
Grafik perubahan dutty cycle saat diberi tegangan input berubah dengan set poin tegangan output $18 \mathrm{~V}$ dengan beban tetap ditunjukkan oleh gambar 16

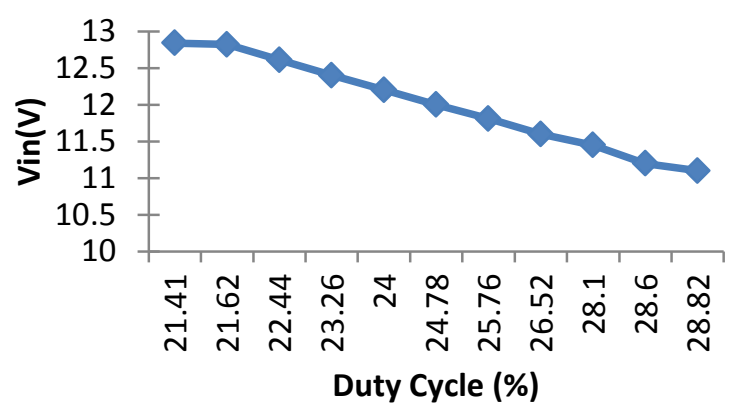

Gambar 16 Hubungan dutty cycle dan $\mathrm{V}_{\text {in }}$

Grafik perubahan dutty cycle saat diberi tegangan input tetap dengan set poin tegangan output berubah-ubah dengan beban tetap ditunjukkan oleh gambar 17.

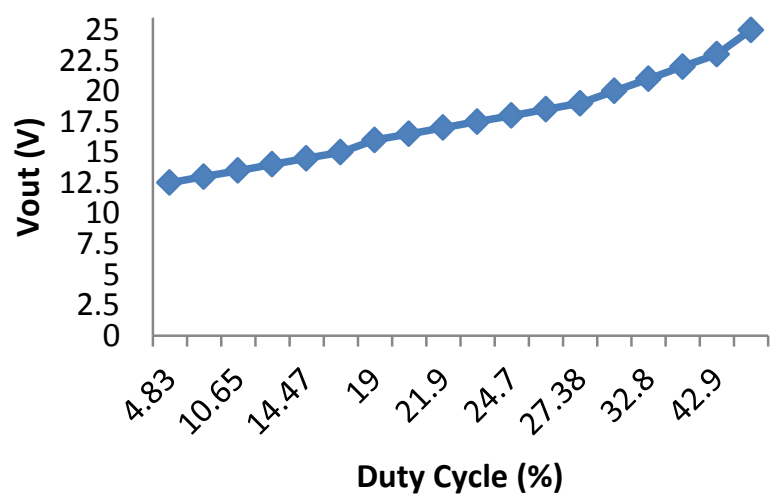

Gambar 17 Hubungan dutty cycle dan $\mathrm{V}_{\text {out }}$

\section{B. Pengujian Hard Switching Boost Konverter}

Boost konverter konvensional menggunakan teknik hard switching sehingga terjadi rugi pensaklaran saat on dan saat off, hal tersebut ditunjukkan oleh bentuk gelombang dari gambar 18.

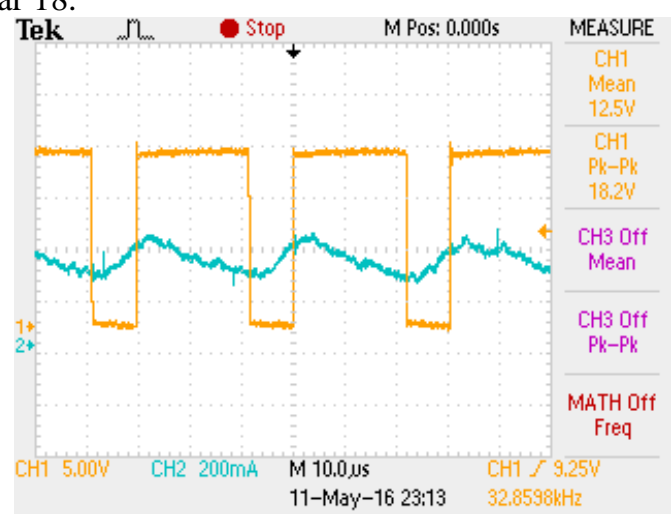

Gambar 18 Bentuk gelombang arus (channel 2 ) dan gelombang tegangan(channel 1) yang terjadi saat saklar MOSFET boost konverter konvensonal diswitching.

\section{Pengujian Soft Switching Boost Konverter dengan SARC}

Bentuk gelombang arus dan tegangan MOSFET IRF540 saat diswitching ditunjukkan melalui gambar 19, dari gambar tersebut konverter meraih zero voltage switch.

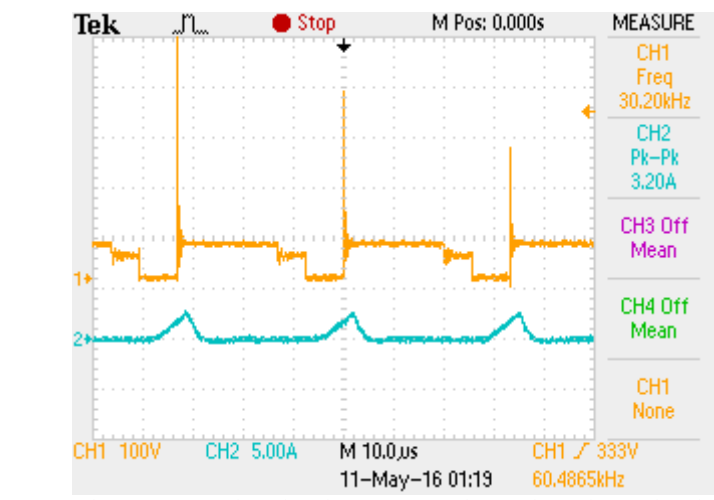

Gambar 19 Bentuk gelombang arus (channel 2 ) dan gelombang tegangan(channel 1) yang terjadi saat saklar MOSFET soft switching boost konverter diswitching.

Dari hasil pungujian efisiensi kedua jenis topologi boost konverter tersebut, diperoleh hasil pengijian pada saat boost konverter hard switching dan soft switching dioperasikan pada daya output maksimum efisiensi boost konverter soft switching unggul sebesar $2.5 \%$. Pada rangkaian soft switching boost konverter dengan SARC terdapat induktor resonansi yang turut berperan memberikan energi ke output konverter, sehingga soft switching boost konverter dengan SARC mempunyai efisiensi yang lebih tinggi dibanding konverter konvensional. Setelah dilakukan pengujian pada kedua jenis boost konverter tersebut, maka dapat dibandingkan efisiensi kedua boost konverter tersebut, perbandingan efisiensi tersebut disajikan pada gambar 20 .

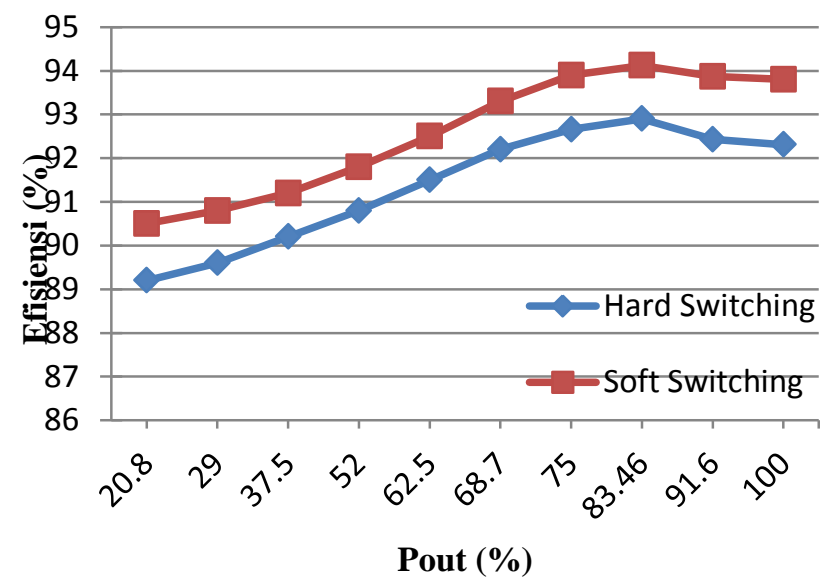

Gambar 20 Grafik perbandingan efisiensi antara hard switching boost konverter dan soft switching boost konverter

\section{KESIMPULAN}

Berdasarkan analisis data hasil simulasi dan pengujian implementasi alat soft switching boost konverter dengan tambahan SARC, dapat disimpulkan beberapa hal sebagai berikut:

1. Soft switching boost konverter dengan SARC mempunyai efisiensi yang lebih tinggi dibanding boost konverter konvensional, karena soft switching boost konverter dengan SARC telah meraih zero voltage switch berdasarkan dari implementasi alat dan telah meraih zero voltage switch dan zero current switch berdasarkan dari hasil simulasi.

2. Boost konverter soft switching dengan SARC memiliki efisiensi maksimum sebesar $94.4 \%$ pada daya output sebesar 40 watt. 


\section{DAFTAR PUSTAKA}

[1] Sang-Hoon Park, Gil-Ro Cha, Yong-Chae Jung, and Chung-Yuen Won, " Design and Application for PV Generation System Using a Soft Switching Boost Converter With SARC", IEEE, Vol. 57, No 2 February 2010. 